\title{
HOW BIG IS CHINA'S DIGITAL ECONOMY?
}

ALICIA GARCIA HERRERO AND JIANWEI XU

This paper reviews international measures of the digital economy and compares them with those developed by Chinese officials and private sources. Given the lack of comparability, we use China's input and output and census data to come up with an internationally comparable estimate of the size of China's information and communication technology (ICT) sector (the core of digital economy), in terms of both value added and employment.

Based on the latest available statistics, our measurements indicate that China's digital economy is not bigger relative to the size of the Chinese economy than the OECD average, especially in terms of ICT employment. This finding, which might look striking based on the current perception of China's digital economy, masks large differences across regions (with Beijing, Guangdong and Shanghai ahead of the OECD average).

Alicia Garcia Herrero (alicia.garcia-herrero@bruegel.org) is a Senior Fellow at Bruegel. Jianwei Xu (jianwei.xu@bruegel.org) is a visiting scholar at Bruegel. 


\section{Introduction}

In the international innovation race, the digital sector has probably been China's showcase. The rise of influential Chinese digital giants, including Baidu, Alibaba, Tencent and Xiaomi (known together by the acronym BATX), has shown the world that China is a global leader in digital innovation (OECD, 2017a). Beyond its domestic market, international statistics clearly point to China's leading role in exporting digital goods and services. Given that China is densely populated with a fast-growing economy, it is not surprising that China has started to influence the global digital market. But is China exploiting its full potential in this area? To answer this question, we assess how big China's digital economy is relative to the rest of its economy, and how China performs compared to the rest of the world.

The importance of the question, at international level, is reflected by the prominence the digital economy is given in $\mathrm{G} 20$ meetings and other international forums, and by ongoing work by the Organisation for Economic Cooperation and Development, the International Monetary Fund and others $(G 20,2017)$. At the national level, the Chinese government, through its statistical agency, the National Bureau of Statistics (NBS), has embarked on a bold project to measure China's new economy, including its digital economy. While there is no official estimate so far, NBS has reported a Digital Economy index as a subsection of a broader self-defined New Economy index (NBS, 2017a). This index, though narrow, points to very rapid growth, in line with other similar indices compiled by the private sector, in particular the Caixin digital economy index (Caixin, 2017).

However, a review of current practices in the measurement of the digital economy at the international level shows that, so far, no comparison is really made using the standard measures of digital economy, apart from measuring Chinese trade in digital goods and services. To fill that gap, we have developed our own estimate of the size of China's digital economy, understood as the size of the information and communication technology (ICT) sector. To that end, we have matched the economic activity classifications from the International Standard Industrial Classification of All Economic Activities (ISIC) with Chinese classifications using China's input-output (IO) table. In addition, we have also measured how much China's ICT sector contributes to employment.

Our results show that, compared to OECD countries, the size of China's digital economy relative to its economy as a whole ranks below the OECD average in terms of the value added and employment created. While relevant for their comparability with other countries, these results should be treated with caution because the available Chinese data is somewhat dated and limited ( 10 table only for 2012 and population census only for 2010) and the digital economy has developed very rapidly in the last few years. This, however, is also the case for comparable data for other countries, so the question remains if China's digital economy has developed much faster than the digital economies of other countries in the past few years. To corroborate the OECD's findings on the rapid development of China's digital economy, we use the official value added growth rate information for ICT manufacturing firms to estimate the ICT value added after 2012. Notwithstanding our conclusion that the gap between the relative size of the digital economy in China and the OECD average is narrowing, we confirm that China remains below the $O E C D$ average in this respect.

Also, though the development of the digital economy in China might lag the OECD average, the key importance for China of the digital sector should not be understated. First, China is a developing country with dual characteristics; it still has a large proportion of rural employment, which cannot be absorbed into the digital sector. Second, labour productivity in the digital sector relative to the country average is higher in China than in OECD countries, meaning that the digital sector is driving the Chinese economy to a greater extent than in other countries. Third, there are several regions in China, such as Beijing, Shanghai and Guangdong, which have shown very strong digital growth. The relatively low level 
of digital development is dragged down by some low-development provinces such as Tibet, Yunnan and Guizhou.

\section{What do international measures of the digital economy tell us about China?}

International efforts to measure and compare the size and growth of the digital economy have only started recently. In the 2017 G20 Digital Economy Ministerial Declaration ${ }^{1}$, the IMF and OECD were tasked with working on a programme to analyse the impact of digitalisation on measures of GDP (G20, 2017). An earlier attempt was made by the OECD in a series of publications on the digital economy outlook (OECD, 2012, 2015, 2017b).

Notwithstanding these analyses, the size of the digital economy has so far only been officially reported in some developed countries, such as Japan and Korea. In both cases, the reported share of value added in information and communication technology (ICT), a core activity of the digital economy, as a percentage of total value added, is among the highest in OECD countries. Unfortunately, no comparable information exists for China (Figure 1 and 2).

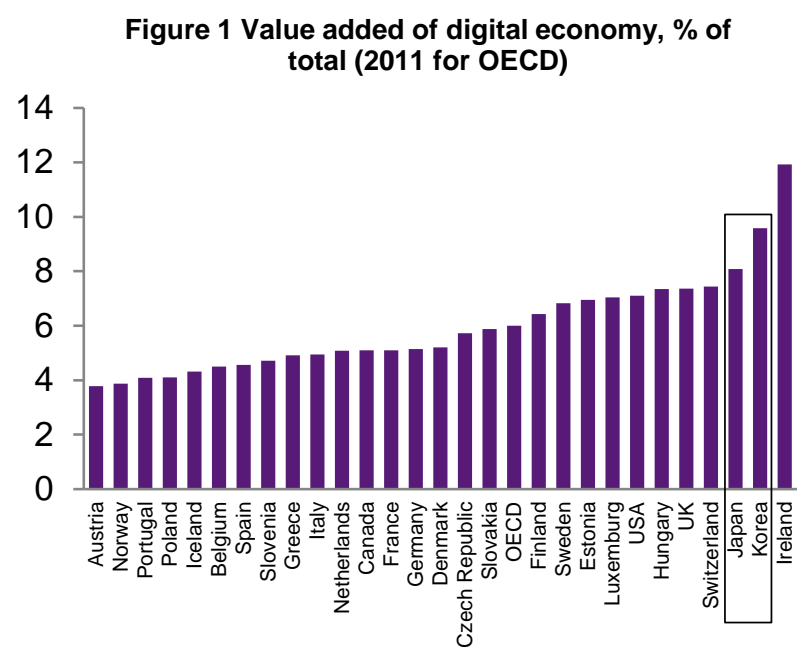

Source: OECD, Natixis
Figure 2 Employment in the ICT sector, \% of total (2011 for OECD)

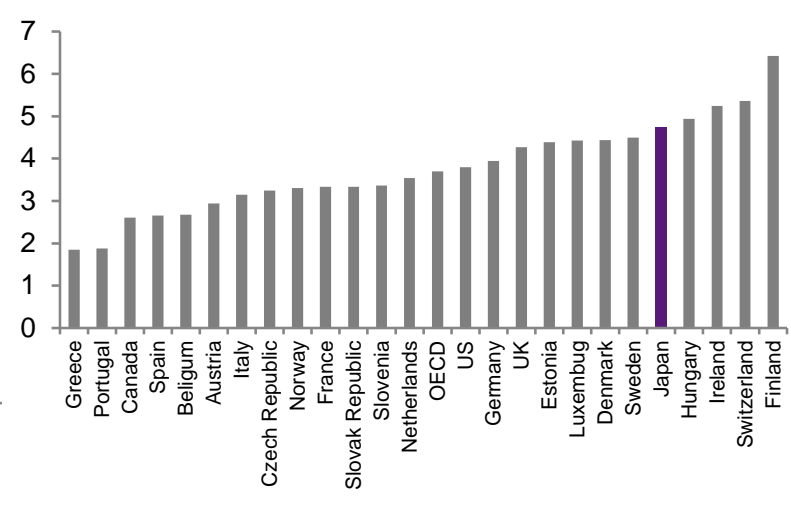

Source: OECD (2017a, 2017b).

The only internationally comparable data available for China in the OECD Digital Economy Outlook relates to ICT exports (OECD, 2015). It shows that China is a leading power in the gross exports of ICT goods (Figure 3). Our calculation using the latest trade data from the World Bank World Development Indicators database confirmed this by showing that the value of ICT goods exported by China reached approximately $\$ 600$ in 2015, equivalent to 26 percent of total exports from China (Figure 4).

\footnotetext{
${ }^{1}$ See www.unctad.org/meetings/es/Contribution/dtl_eWeek2017c02-G20_en.pdf.
} 
Figure 3 ICT goods exports \% of world total ICT goods exports

(2015)

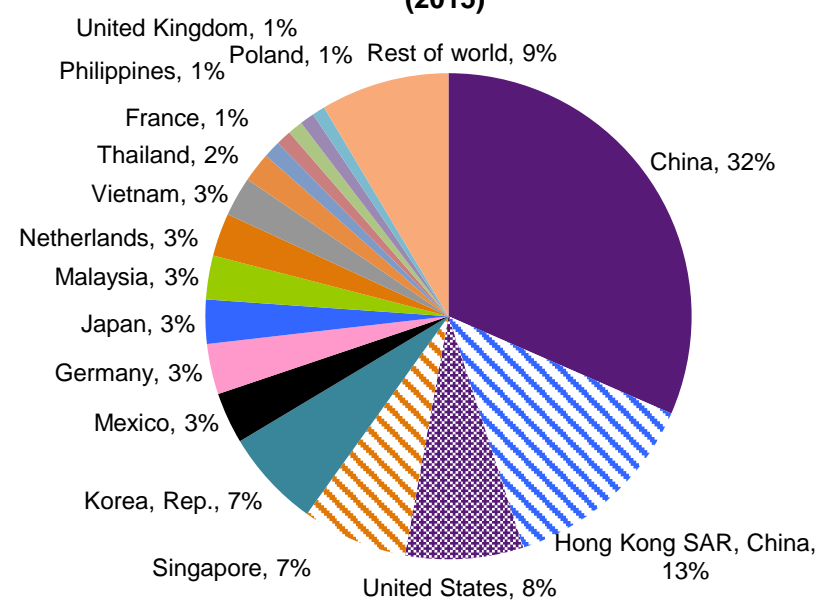

Source: Bruegel based on World Bank WDI Data.
Figure 4 ICT goods exports $\%$ of the country's total goods exported (2015)

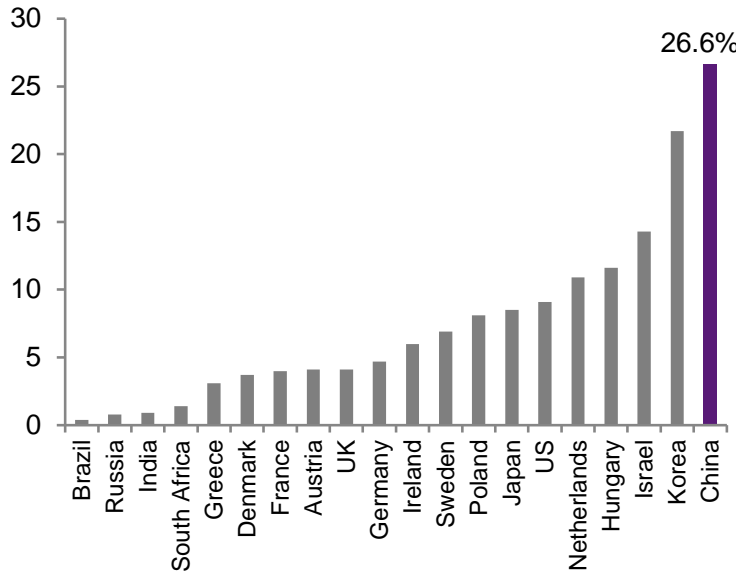

Source: Bruegel based on World Bank WDI Data.

ICT also plays an important role in China's exports of services, accounting for 40 percent of China's services exports. The ICT export services include the wholesaling, renting of machinery, equipment and supplies, and the telecommunication and computer related services. This is a higher share than those of Japan or the US (Figure 5) although lower than those of the Philippines, Israel, Brazil, Sweden, Germany and France. This translates into China having a quite small share of global ICT service exports, at 6 percent (Figure 6).

Figure 5 ICT services exports $\%$ of total services exports by country (2015)

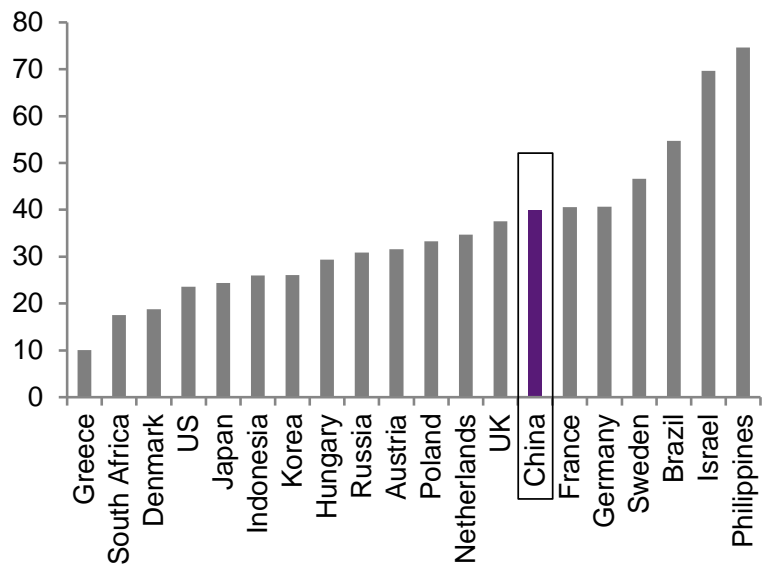

Source: Bruegel based on World Bank WDI Data.
Figure 6: exports of ICT services as \% of world total ICT service exports

(2015)

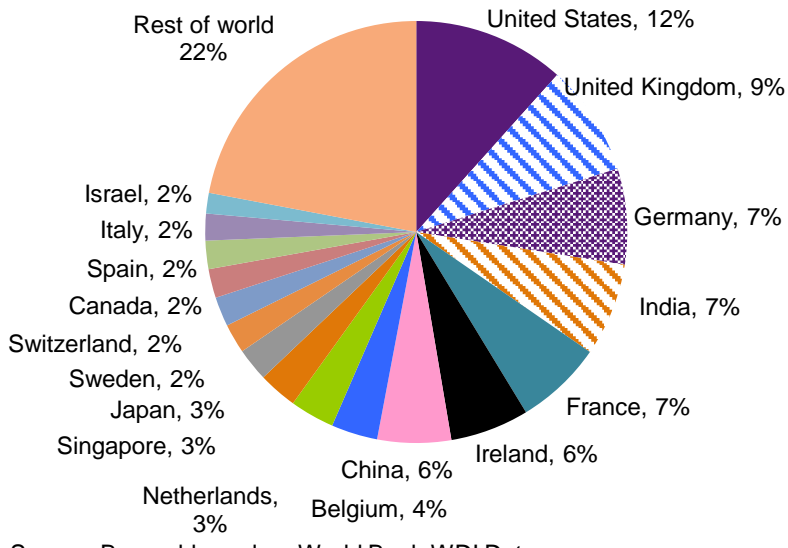

Source: Bruegel based on World Bank WDI Data.

While China's ICT exports look quite massive, based on comparable data, this does not give a full picture of the size of China's digital economy. This is particularly the case when focusing on the value added from the digital economy, because ICT products, such as computers and smartphones, are assembled in - and exported from - China, but with a good part of their value added generated elsewhere. China's value added embedded in its ICT exports is only half of total value of the ICT exports, which brings China's share of global ICT exports down to 11 percent (Figure ?), below the US share. 


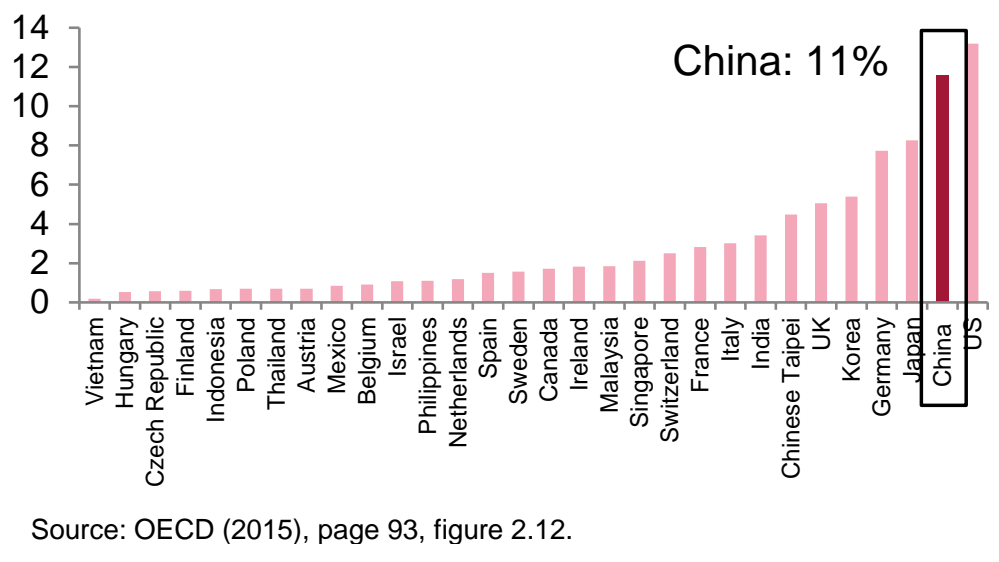

The marked difference between China's share of ICT gross exports and value added in ICT exports points to the importance of using value added data to estimate the size of the digital economy in China.

\section{Official and private measurements of China's digital economy}

During its G20 presidency in 2016, China supported global efforts to agree on a definition of the digital economy within the G20 Digital Economy Development and Cooperation Initiative. That initiative defined the digital economy as: "a broad range of activities that include using digitalised information and knowledge as the key factor of production, modern information networks as an important activity space, and the effective use of ICT as an important driver of productivity growth and economic structure optimisation".

However, when it comes to the actual measurement of the digital economy, it is much less clear that there is consensus, including in China. The mainstream view in China, voiced by the Chinese National Bureau of Statistics (NBS) is that the sectoral-based analysis adopted in many OECD countries might overlook that only some products in some sectors are linked to the digital economy while others are not. This is why the NBS has started to move to product-level data within some relevant sectors. In other words, the NBS believes a better strategy is to also measure the digital economy at the product level (NBS, 2017b). While relevant, there is no doubt that measuring the digital economy at the product level is very challenging, as product-level information is not widely available for all sectors. Some internal trials in China on product-level measurement of the digital economy have been reportedly carried out, but details have not been reported (NBS, 2017c).

In the meantime, the NBS has been focusing on measuring the so-called 'New Economy', partly as a response to the government's long-lasting strategy to develop strategically important sectors and increase the relative size of the 'new' economy. Although the New Economy is a much broader concept than the digital economy, with even, for example, the traditional Chinese medicine and environmental protection sectors included, the digital economy is treated as a sub-index of NBS's measurement of the New Economy. According to the first New Economy Report published by the NBS in August 2017, the NBS used three statistical methods to calculate the value added of the New Economy (NBS, $2017 \mathrm{~d}$ ), including the direct measurement method, value added ratio extrapolation method and the proportion method. These methods were applied to different economic activities according to availability of data (Table 1). NBS has not published a specific methodology for the measurement of the digital economy, but we believe the same methodology used for the New Economy could also be applied to the digital economy from the official perspective. 
Table 1: 'Three NEWs' (New Industry, New types of business and New business models) value added computation methods

\begin{tabular}{|c|c|c|c|c|}
\hline Method & & \multicolumn{2}{|l|}{ Formula } & Scope of application \\
\hline $\begin{array}{l}\text { Direct accounting } \\
\text { method }\end{array}$ & $\begin{array}{l}\text { Directly compute by } \\
\text { production } \\
\text { approach or } \\
\text { expenditure } \\
\text { approach }\end{array}$ & $\begin{array}{l}\text { Production approach: } \\
\text { Value added = Final } \\
\text { output - } \\
\text { Intermediate input }\end{array}$ & $\begin{array}{l}\text { Expenditure } \\
\text { approach: } \\
\text { Value added }= \\
\text { Payroll expenses }+ \\
\text { Net production tax }+ \\
\text { PPE depreciation }+ \\
\text { Retained earnings }\end{array}$ & $\begin{array}{l}\text { Applicable to industries } \\
\text { with more detailed financial } \\
\text { information, for example, } \\
\text { industrial strategic } \\
\text { emerging industry, high- } \\
\text { tech manufacturing, and } \\
\text { financial service industry. }\end{array}$ \\
\hline $\begin{array}{l}\text { Value added ratio } \\
\text { estimation method }\end{array}$ & $\begin{array}{l}\text { Estimate from total } \\
\text { output and value } \\
\text { added ratio }\end{array}$ & \multicolumn{2}{|c|}{$\begin{array}{l}\text { Value added }=\text { Total output } \times \text { Value added } \\
\text { ratio } \\
\text { (value added ratio is computed from } \\
\text { economic census or related statistical } \\
\text { surveys.) }\end{array}$} & $\begin{array}{l}\text { Applicable to industries } \\
\text { with less detailed financial } \\
\text { information but statistical } \\
\text { reports that reveal output of } \\
\text { "Three New" production } \\
\text { activities, like other new } \\
\text { service industry, high-tech } \\
\text { service industry, } \\
\text { technology business } \\
\text { incubator, e-commerce, city } \\
\text { business complex, national } \\
\text { economic and } \\
\text { technological development } \\
\text { zones, etc.. }\end{array}$ \\
\hline $\begin{array}{l}\text { Proportional } \\
\text { computing method }\end{array}$ & $\begin{array}{l}\text { Estimate by the } \\
\text { proportion of } \\
\text { respective industry } \\
\text { output of total } \\
\text { output }\end{array}$ & \multicolumn{2}{|c|}{$\begin{array}{l}\text { Value added = Respective industry value } \\
\text { added } \times \text { ["Three NEWs" output } \div \text { Respective } \\
\text { industry total output] } \\
\text { (the share of "Three NEWs" output in } \\
\text { respective industry total output is computed } \\
\text { from economic census or related statistical } \\
\text { surveys.) }\end{array}$} & $\begin{array}{l}\text { Applicable to industries } \\
\text { with no detailed financial } \\
\text { information but economic } \\
\text { census or related statistical } \\
\text { surveys that show the } \\
\text { proportional output, like } \\
\text { strategic emerging service } \\
\text { industry. }\end{array}$ \\
\hline
\end{tabular}

Source: China NBS (2017d).

Although the NBS has described methodologies, no official data has been released for either the New Economy index or the digital economy index. In the August 2017 report, the NBS only included an index characterising the growth rate of the New Economy with a related sub-index for the digital economy. The methodology for the official digital economy index is fairly simple, compared to the previous official methodology discussion, which used an alternative big data method to construct the measure from the users' perspective. The digital economy index only included five specific indicators: users with access to broadband internet, mobile internet users, mobile internet access traffic, ecommerce transactions, and online retail sales as a proportion of total retail sales. The official results show that the digital economy in China grew nearly 40 percent in 2015 (China NBS, 2017a). 
Table 2: Comparison of China's digital economy coverage with the OECD

\begin{tabular}{|c|c|c|}
\hline OECD Measurement & $\begin{array}{l}\text { China: Caixin Digital Economy } \\
\text { Measurement }\end{array}$ & $\begin{array}{l}\text { China: NBS Digital } \\
\text { Economy Index } \\
\text { Measurement }\end{array}$ \\
\hline $\begin{array}{l}\text { Manufacturing activity: } \\
\text { 1. ISIC [Rev. 3.1] } 3000 \text { - Office, accounting and computing } \\
\text { machinery } \\
\text { 2. ISIC [Rev. 3.1] } 3130 \text { - Insulated wire and cable } \\
\text { 3. ISIC [Rev. 3.1] } 3210 \text { - Electronic valves and tubes and } \\
\text { other electronic components } \\
\text { 4. ISIC [Rev. 3.1] } 3220 \text { - Television and radio transmitters } \\
\text { and apparatus for line telephony and line telegraphy } \\
\text { 5. ISIC [Rev. 3.1] } 3230 \text { - Television and radio receivers, } \\
\text { sound or video recording or reproducing apparatus, and } \\
\text { associated goods } \\
\text { 6. ISIC [Rev. 3.1] } 3312 \text { - Instruments and appliances for } \\
\text { measuring, checking, testing, navigating and other } \\
\text { purposes, except industrial process equipment } \\
\text { 7. ISIC (Rev. 3.1] } 3313 \text { - Industrial process equipment } \\
\text { Service activity: } \\
\text { 1. ISIC (Rev. 3.1] } 5151 \text { - Wholesale of computers, } \\
\text { computer peripheral equipment and software } \\
\text { 2. ISIC [Rev. 3.1] } 5152 \text { - Wholesale of electronic and } \\
\text { telecommunications parts and equipment } \\
\text { 3. ISIC [Rev. 3.1] } 6420 \text { - Telecommunications } \\
\text { 4. ISIC [Rev. 3.1] } 7123 \text { - Renting of office machinery and } \\
\text { equipment (including computers] } \\
\text { 5. Computer and related activities. }\end{array}$ & $\begin{array}{l}\text { CIC } 6510 \text { - Software } \\
\text { development } \\
\text { CIC } 6520 \text { - Information } \\
\text { technology service activities } \\
\text { (1) information integration, [2] } \\
\text { information consulting (3) data } \\
\text { store and processing } \\
\text { (4) Digital game/movie and } \\
\text { software service } \\
\text { (5) client interactive service }\end{array}$ & $\begin{array}{l}\text { 1. Internet } \\
\text { Broadband access } \\
\text { users } \\
\text { 2. Mobile internet } \\
\text { users } \\
\text { 3. Mobile internet } \\
\text { access traffic } \\
\text { 4. e-commerce } \\
\text { transaction } \\
\text { 5. The share of } \\
\text { online retail sales } \\
\text { over total retail sales }\end{array}$ \\
\hline
\end{tabular}

Source: OECD(2015), Caixin (2017), China NBS (2017a).

The NBS is not the only institution attempting to measure the development of the digital economy in China. Another famous institution, Caixin - China's business and financial news group - has also reported its own estimates of the digital economy. Caixin uses section 2.3 of the official Classification of Emerging Sectors of Strategic Importance published by the NBS in 2012 to define the digital economy sector (NBS, 2012). This actually includes only two key sectors related to the digital economy: high-end software development and new information technology services (Table 2). Moreover, Caixin adopted the standard production function method, with measurement of capital, labour and innovation inputs respectively, as a basis to estimate the development of the digital economy. Nearly all of Caixin's measurements on the inputs are collected through big data analysis. For example, wage and employment data are assembled through cooperation with an anonymous online job platform. The Caixin digital economy index presents an even brighter picture than the official one. According to its index, the digital economy grew by 176 percent from January 2016 to April 2017. 
Table 3: Caixin's method and data source for the estimation of digital economy index

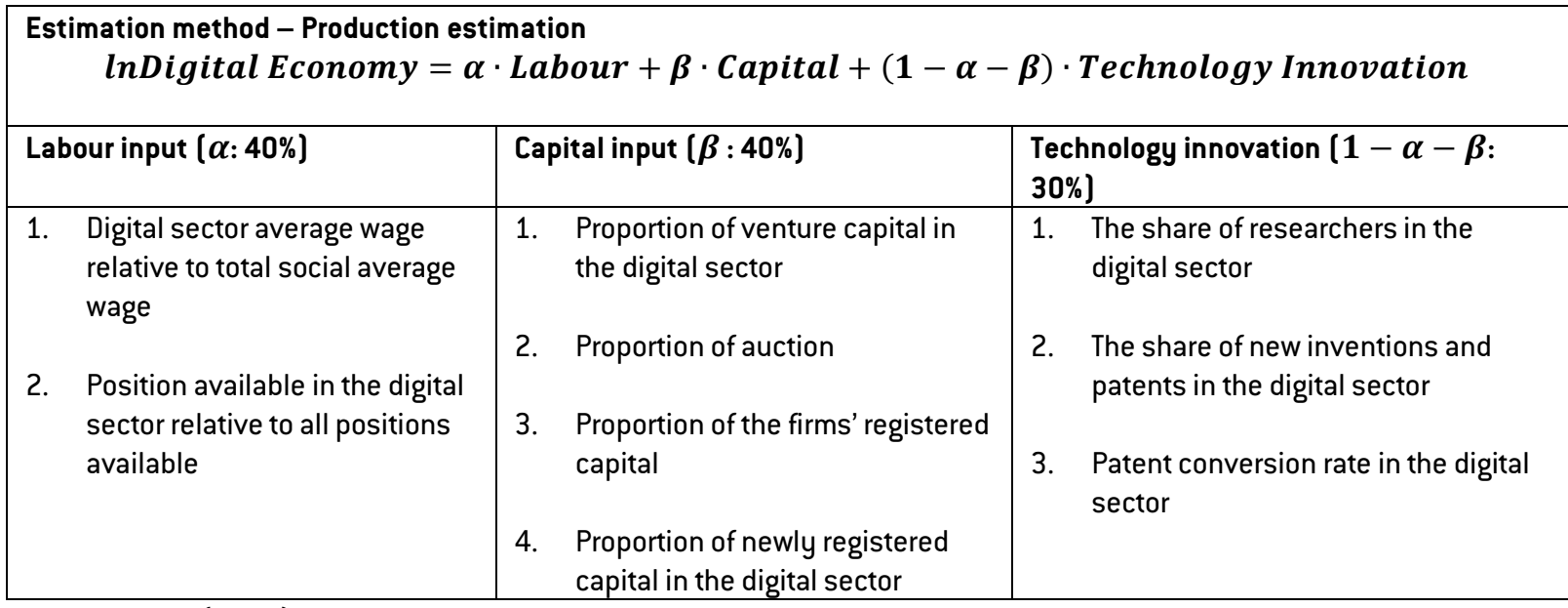

Source: Caixin[2017).

Although most of the results from the above indices are promising and seem to be consistent with the OECD's analysis of digital development in China using trade data, their methodologies seem to be not comparable with the OECD standard for measuring the ICT sector. Moreover, one cannot yet estimate how large the Chinese digital economy is relative to the total Chinese economy.

\section{Our own measurement of China's digital economy}

In this section, we use the publicly available official data to provide a measurement of China's digital economy in a way that is comparable to the OECD methodology. Specifically, we rely on two types of data - China's input-output table (2012) and China's Population Census [2010) - to calculate value added and employment following the OECD's methodology. The cross-sectional characteristics of the two datasets means we can only arrive at a static conclusion for China's digital economy, so this can be taken as only an addition to the previous two measures capturing the growth rate of the digital economy.

- The input-output table is the only data source that provides value added information for narrowly defined sectors, including for services, but the latest table dates from 2012. To the best of our knowledge, all other data sources in China either only provide value added information for the industrial sector, or measure services value added using a very broad classification, which makes it impossible to disentangle the digital activities.

- The Population Census, conducted every ten years, is probably the most reliable source of information on employment activities in China at narrowly defined sectoral level. Employment status is also provided for each person covered by the census.

However, even with the availability of the above two databases, the calculation of the size of the digital economy in China is not easy. In particular, the industry classification used in China does not follow the international standard - ISIC, or NACE. To bring our estimate as close as possible to the OECD definition, we selected the sectors that most closely matched the OECD definition and classified the following as digital sectors: [1] Digital manufactured goods: office, accounting and computing devices; telecommunication devices; measuring devices; electronic and optical products; computers; (2) Digital services: telecommunication services; software and information services. Table 4 compares our definition with that of the OECD. 


\section{Table 4: China's and the OECD's definitions of ICT sectors}

\begin{tabular}{|l|l|}
\hline Our classification for China & OECD definition for ICT \\
\hline $\begin{array}{l}\text { 1. Office machinery } \\
\text { 2. Computer }\end{array}$ & $\begin{array}{l}\text { 1. ISIC (Rev. 3.1) 3000 - Office, accounting and computing } \\
\text { machinery }\end{array}$ \\
\hline 3. Wire, cable and related apparatus & 2. ISIC (Rev. 3.1) 3130 - Insulated wire and cable \\
\hline 4.Telecommunication devices & $\begin{array}{l}\text { 3. ISIC (Rev. 3.1) 3210 - Electronic valves and tubes and } \\
\text { other electronic components }\end{array}$ \\
\hline $\begin{array}{l}\text { 5.TV broadcast, radio and radar devices } \\
\text { Video devices }\end{array}$ & $\begin{array}{l}\text { 4. ISIC (Rev. 3.1) 3220 - Television and radio transmitters } \\
\text { and apparatus for line telephony and line telegraphy } \\
\text { 5. ISIC (Rev. 3.1) 3230 - Television and radio receivers, } \\
\text { sound or video recording or reproducing apparatus, and } \\
\text { associated goods }\end{array}$ \\
\hline 6.Measurement devices & $\begin{array}{l}\text { 6. ISIC (Rev. 3.1) 3312 - Instruments and appliances for } \\
\text { measuring, checking, testing, navigating and other } \\
\text { purposes, except industrial process equipment }\end{array}$ \\
\hline 7.Electronic process equipment & 7. ISIC (Rev. 3.1) 3313 - Industrial process equipment \\
\hline 8.Electronic and telecommunication services & $\begin{array}{l}\text { 8. ISIC (Rev. 3.1) 5152 - Wholesale of electronic and } \\
\text { telecommunications parts and equipment } \\
\text { 9. ISIC (Rev. 3.1) 6420 - Telecommunications }\end{array}$ \\
\hline 9.Software and information technology services & $\begin{array}{l}\text { 10. ISIC (Rev. 3.1) 5151 - Wholesale of computers, } \\
\text { computer peripheral equipment and software } \\
11 . \text { ISIC (Rev. 3.1) 7123 - Renting of office machinery and } \\
\text { equipment (including computers) } \\
12 . \text { Computer and related activities. }\end{array}$ \\
\hline
\end{tabular}

Source: OECD (2015), China's 2012 Input-Output Table.

Figures 8 and 9 report our estimates of value added and employment respectively. In contrast to what the OECD's export and R\&D measures have shown, both the value added ( 4.8 percent) and employment (2.6 percent) share of the ICT sector in our estimates are lower than the OECD average ( 6 percent and 3.7 percent, respectively), and are far behind Japan. The result is more consistent with the OECD estimates of domestic value added embedded in exports from China, which shows a much lower ratio than for gross exports. In other words, China seems, according to our estimates, to produce more ICT products, but the value added and employment invested in the digital economy is less strong.

Figure 8 Value-added of digital economy, $\%$ of total value-added by country

(2011 for OECD and 2012 for China)

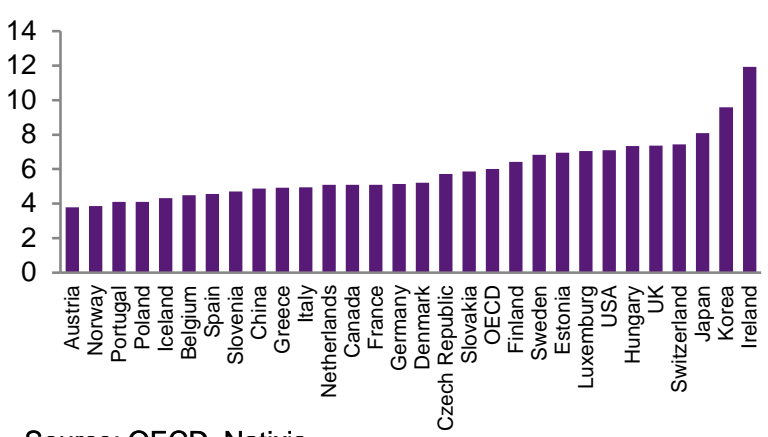

Source: OECD, Natixis
Figure 9

Employment in the ICT sector \% of total employment by country (2011 for OECD and 2010 for China)

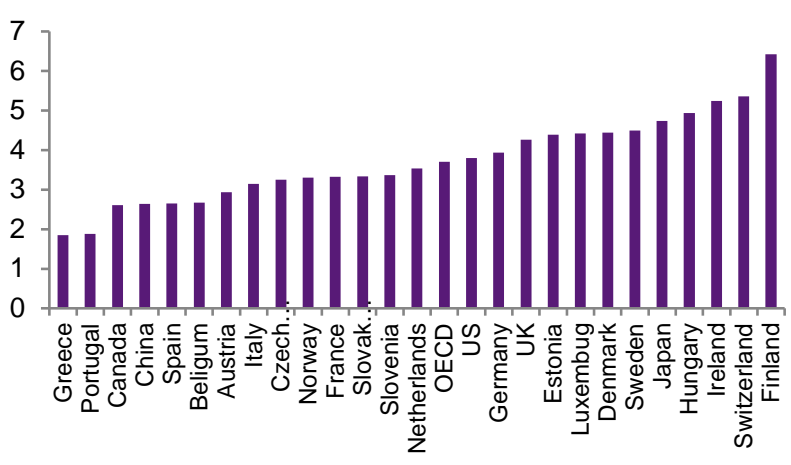

Source: OECD, Natixis

However, this does not necessarily mean the digital sector in China is less developed. After all, the country is a low-income developing economy with great differences in development levels across the country. Annual GDP per capita is still only $\$ 8123$ in 2016 , and the rural population accounts for 43 percent of the total population. If we only consider digital employment in urban areas, the share reaches 4.53 percent, which is significantly higher than the OECD average. 
Another feature of China's digital sector is its concentration on manufacturing activities. Manufacturing production, of goods such as electronics, computers and telecommunication devices, amount to about 55 percent of total value added in China's ICT sector. In turn, service activities only contribute 45 percent of total value added in the ICT sector. This implies that China's digital economy is still deeply rooted in manufacturing. Moving forward, China's transition towards a more service-oriented economy should also push ICT services further.

Figure 10: Value-added composition (2012)

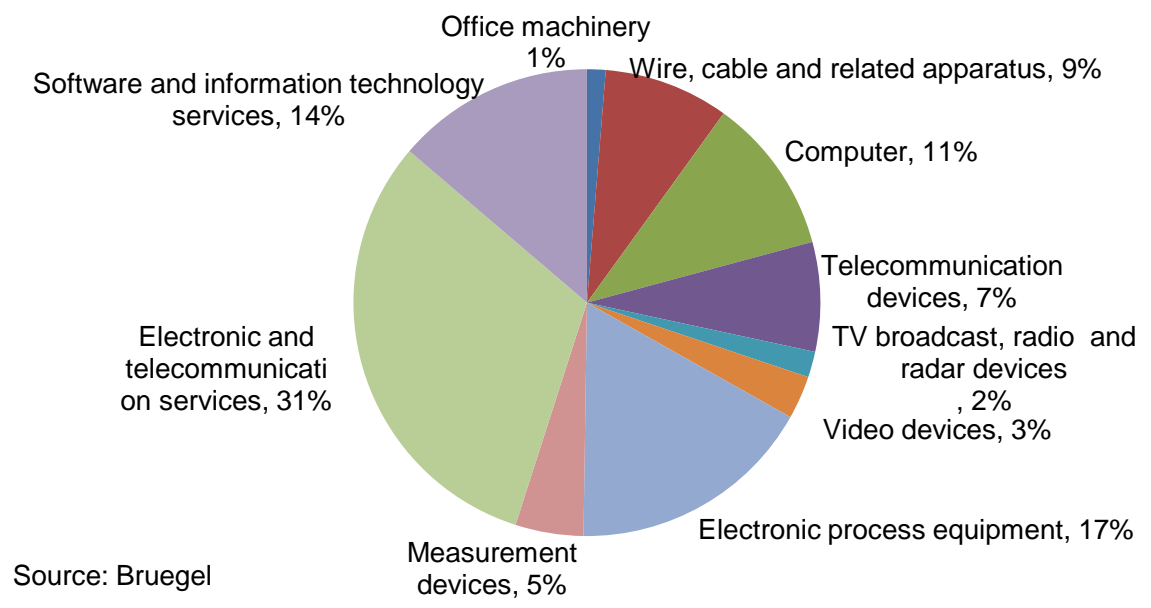

Moreover, while labour productivity in the Chinese ICT sector is about 1.8 times greater than China's average labour productivity, labour productivity in the digital sector in the OECD is only 1.6 times higher than the average. In other words, the digital sector is contributing more to China's economic growth than in OECD countries (Figure 11). Moreover, the low degree of ICT development also masks the unequal development of digital sectors within China. In terms of ICT employment share, leading cities such as Beijing, Shanghai and Guangdong, have already shown very high ratios -8.4 percent, 8.2 percent and 7.9 percent, respectively - exceeding nearly all major OECD countries. However, ICT employment shares in the much less developed regions such as Tibet and Guizhou are less than 0.1 percent (Figure 12).

Figure 11 Relative labour productivity comparison

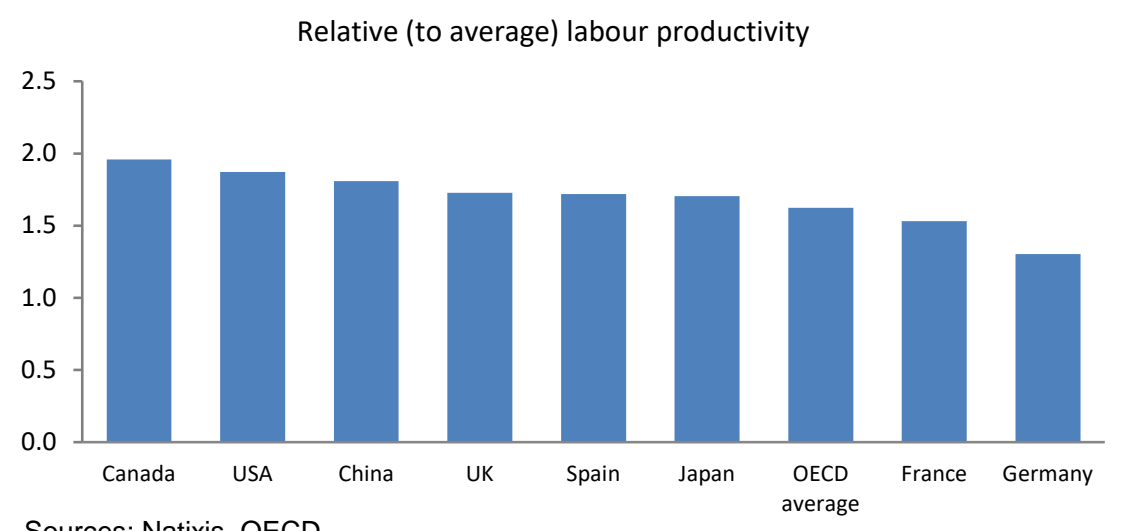

Sources: Natixis, OECD

Note: Consistent with our earlier estimates, the calculation of labor productivity takes the employment data from 2010 and the value added data from 2012. 


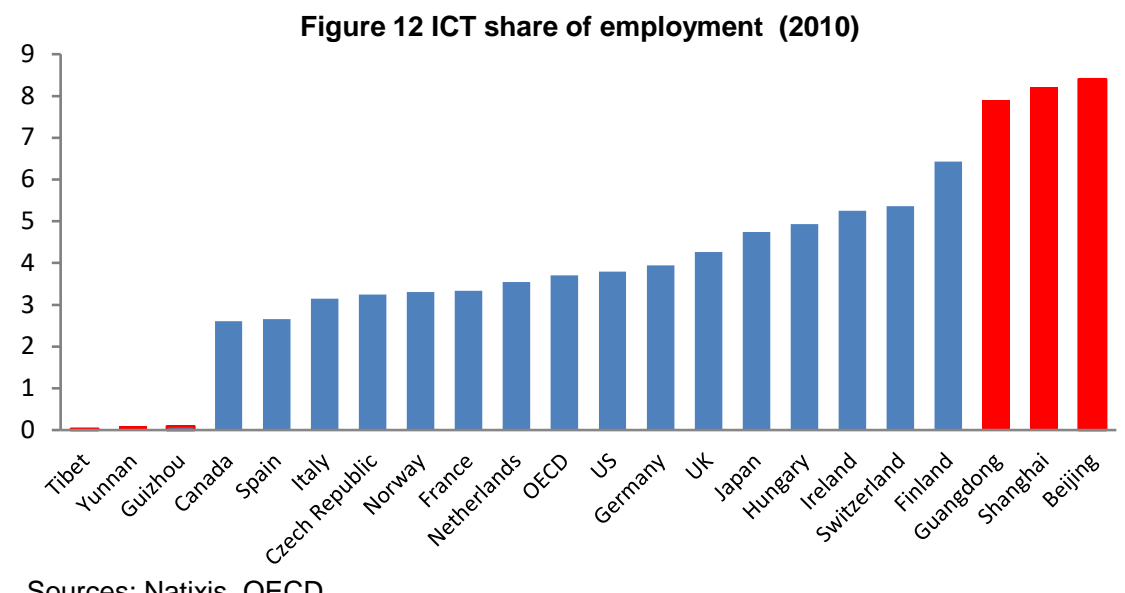

Sources: Natixis, OECD

\section{Recent developments in China's digital economy}

One of the most obvious challenges to our finding of a relatively small digital economy in China is that we can only measure the value added of the ICT sector as it was in 2012. While this is also true for the rest of countries in the OECD sample, making our findings for China comparable with the rest, it is also the case that China's progress since then seems to have been very rapid, based on the emergence of giant high-tech companies. The indices developed by the NBS and Caixin point to annual growth rates since 2016 of between 40 percent and 176 percent. However, such growth rates do not answer the question of the size of China's digital economy as they are indices and are not even expressed in terms of value added. In addition, they are non-standard in the sense that they have been arrived at using big-data analysis.

In this context, and with the already described data constraints, we address the issue of the change in the size of China's digital economy. We chose a narrower definition of value added in the ICT sector, namely the ICT manufacturing value for industrial firms, as reported by China's Ministry of Industry and Information Technology, and we calculated the growth rate. This indicator has two clear weaknesses compared to the more general estimates of ICT value added. First, it is only a measure of manufacturing firms, and excludes all service activities. Second, only companies with annual sales above 20 million renminbi are included in the Ministry of Industry and Information Technology data set.

Nevertheless, we conclude that, from 2013 to 2016, China's ICT value added growth rate has hovered above 10 percent, whereas China's average GDP growth rate declined from 7.8 percent to 6.7 percent, echoing our previous finding that the digital sector is indeed driving the Chinese economy (Figure 13). If we take the value added for the ICT sector and other sectors in 2012 as given, and apply this growth rate for the subsequent four years, we can confirm that the ICT sector has increased its size significantly (Figure 14) to reach 5.6 percent of the total value added in 2016. Despite this apparent progress, we should point out that the current level is still no higher than the OECD value added share average of 6 percent in 2012. 
Figure 13 ICT Growth rate versus GDP growth rate for China

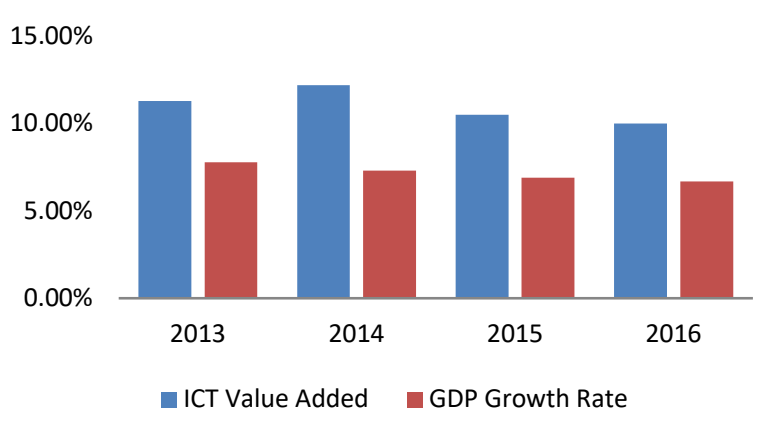

Figure 14 ICT share of Value-added

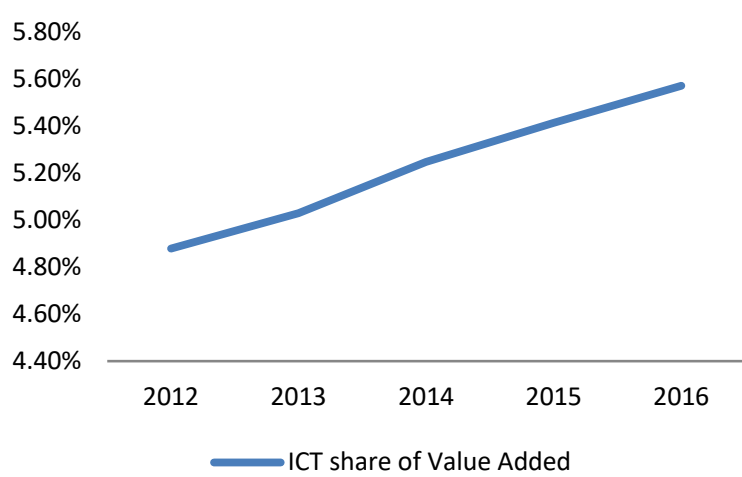

\section{Conclusions}

This paper contributes to the discussion on the measurement of China's digital economy. We briefly introduced the current practice, and proposed our own estimates of the actual size of China's digital economy relative to OECD countries. Using a methodology matched as close as possible to the ISIC standard, we calculated the value added and employment share of ICT activities in China and compare it with $O E C D$ countries. The results show that China is still below the OECD average level of development in the digital sectors, in terms of value added and employment share.

However, the Chinese digital sector has strong potential. First, China still has a very large rural economy. Given that digitalisation is much higher in urban areas, the country's digital share will continue to rise as the process of urbanisation continues. Second, relative labour productivity in digital sectors is higher in China than the OECD average, implying its more important role in boosting the economy. Third, developments in China are unevenly spread, with developed regions such as Beijing and Shanghai seeing even higher employment shares of the ICT sector than OECD countries, but the least-developed Chinese regions lagging quite far behind. If the rate of digital development in leading regions spills over to other regions, a new round of high-tech development can be expected to emerge in the future.

Last but not least, we attempted to obtain a more recent proxy of the growth of China's digital economy by narrowing the definition to the manufacturing sector, for which data is available. We found that, even if the growth of China's manufacturing ICT sector is very fast, China's share of value added in ICT is still very likely to have been no higher than the OECD average in 2016. In other words, China is still catching up in its ICT development with the developed world. 


\section{References}

Caixin (2017), 9 月数字经济指数报告 (September Digital Economy Index Report), available at http://index.caixin.com/2017-10-12/101154872.html.

China NBS (2012), 战略性新兴产业分类 (Classification of Strategic Emerging Sectors), available at http://www.stats.gov.cn/tjsj/tjbz/201301/U020131021375903103360.pdf.

China NBS (2017a), 新动能和新经济稳步增长 (The New Momentum and New Economy are growing robustly]', 2017 新动能新经济报告 (New Economy Report), 中国统计出版社 (China Statistics Press].

China NBS (2017b), “三新”统计 (The New Economy Statistics), available at http:/www.stats.gov.cn/ztjc/zthd/sjtjr/d8jkfr/qt/201709/P020170915597836129730.pdf.

China NBS (2017c), 建立“三新”统计服务经济发展——鲜祖德谈“三新”统计改革与创新 (Establishing New Economy statistical measurement for the service economy - Zude Xian talked about the New Economy statistical reform and innovation], available at http://www.stats.gov.cn/tjgz/tjdt/201704/t20170411 1483047.html.

China NBS (2017d), 新经济统计的构建与实践 (The Establishment and Practice of the New Economy Statistics), 2017 新动能新经济报告 (New Economy Report), 中国统计出版社 (China Statistics Press].

G20 (2017), "G20 Digital Economy Ministerial Declaration: Shaping Digitalisation for an Interconnected World", G20 Digital Economy Ministerial Conference, available at http://unctad.org/meetings/es/Contribution/dtl eWeek2017c02-G20_en.pdf.

OECD (2012), Digital Economy Outlook 2012, available at http://www.oecd.org/sti/ieconomy/oecdinternet-economy-outlook-2012-9789264086463-en.htm.

OECD (2015), Digital Economy Outlook 2015, available at http://www.oecd.org/internet/oecd-digitaleconomy-outlook-2015-9789264232440-en.htm.

OECD (2017a), The Next Production Revolution: Implications for Governments and Business, available at http://dx.doi.org/10.1787/9789264271036-en, 10 May

OECD (2017b), Digital Economy Outlook 2017, available at http://www.oecd.org/internet/oecd-digitaleconomy-outlook-2017-9789264276284-en.htm, 11 0ctober 
(ㄷ) Bruegel 2018. All rights reserved. Short sections, not to exceed two paragraphs, may be quoted in the original language without explicit permission provided that the source is acknowledged. Opinions expressed in this publication are those of the author(s) alone.

Bruegel, Rue de la Charité 33, B-1210 Brussels

$(+32) 22274210$

bruegel

info@bruegel.org

www.bruegel.org 